\title{
Studies on the Degranulation of RBL-2H3 Cells Induced by Traditional Chinese Medicine Injections*
}

\author{
Jia-Ming Tang", Jiong Liu, Wenbin Wu \\ Laboratory Animal Center, Shanghai University of Traditional Chinese Medicine, Shanghai, China \\ Email: tangjiaming@hotmail.com
}

Received August 21, 2012; revised September 29, 2012; accepted October 11, 2012

\begin{abstract}
Aims: To study RBL-2H3 cell degranulation phenomena induced by some TCMIs through cell morphological and ultra-structural observation, released enzyme activity and establish RBL-2H3 cell degranulation test indicated by $\beta$ hexosaminidase activity as a method to evaluate TCMIs at nonclinical stage. Methods: RBL-2H3 cells were used to study the degranulation by co-culture with positive control C48/80 and some TCMIs through morphological and ultrastructure observation, $\beta$-hexosaminidase activity detection. RBL-2H3 cell degranulation test was established to detect $\beta$-hexosaminidase activity caused by 17 kinds of TCMIs and their ingredients. The cytotoxicity effect of some TCMIs on both RBL 2H3 and BRL cells was measured by CCK-8 assay. Results: Toluidine blue staining and ultra-structure of electronic microscope observation of treated RBL-2H3 cells showed degranulation morphologically. Detection of $\beta$ hexosaminidase activity in the supernatant of treated cells showed some TCMIs had elevated enzyme release rates. Further analysis of the ingredients and compound in Tanreqing injection and Shengmai injection showed Scutellaria baicalensis Georgi in Tanreqing injection, Red ginseng and Fructus Schisandrae Chinensis in Shengmai injection were responsible to the degranulation of RBL-2H3 cells. Osmotic pressures and $\mathrm{pH}$ influenced RBL-2H3 degranulation. High Osmotic pressure of Tanreqing injection and low $\mathrm{pH}$ of chlorogenic acid at 2.5 and $5.0 \mathrm{mmol} / \mathrm{L}$ congcentration might be responsible to high $\beta$-hexosaminidase activity. Most of the TCMIs inducing degranulation had cytotoxicity effect for both RBL-2H3 and BRL cells, but some TCMIs inducing degranulation had no cytotoxicity effect. Conclusion: Some TCMIs can induce degranulation of RBL-2H3 cells; RBL-2H3 cell degranulation test can be used in non-clinical stage to detect the risk causing anaphylactoid reactions. Osmotic pressures and $\mathrm{pH}$ influenced RBL-2H3 degranulation, and they should be measured before testing. The mechanism of degranulation caused by some TCMIs is cytotoxic, and some are non-cytotoxic and may be through exicytosis.
\end{abstract}

Keywords: Traditional Chinese Medicine Injection (TCMI); RBL-2H3 Cells; Degranulation; $\beta$-Hexosaminidase; Anaphylactoid Reaction

\section{Introduction}

In recent years, with the widespread use of Traditional Chinese Medicine injections (TCMIs), the adverse reactions reported increased gradually $[1,2]$. Adverse reactions may be caused by many reasons, but allergic reactions are generally considered to be more frequent, more harmful side effects. Based on clinical reports analysis, some cases of the allergic reactions may actually belong to the class of anaphylactoid reactions. The clinical symptoms of both Type I allergic reactions and anaphylactoid reactions are similar and related to the mast cell (MC) degranulation, and MCs are the final effector cells of type I allergic reactions and anaphylactoid reactions. An

\footnotetext{
"Author contribution: Prof. Tang Jiaming designed and wrote the paper Liu Jiong performed the experiments and analyzed the results statistically.

${ }^{\#}$ Correspondence author.
}

important mechanism differentiating anaphylactoid reactions from allergic reactions is that in the former with no immune system involved, and the drugs directly stimulate MCs or basophils to degranulate, or activate the complement bypass through MBL pathway, producing C3a and $\mathrm{C} 4 \mathrm{a}$ in vivo, the latter stimulate MCs or basophils to degranulate and release some bioactive media, such as histamine and leukotriene, causing systemic or local pathophysiological reaction, such as allergic shock, bronchospasm and skin rash et al. [3,4].

Currently the detection techniques and methods of immunotoxicity safety evaluations for TCMIs are based on "Technical Guidelines for Studies of Chinese Medicine \& Natural Drug Immunotoxicity (Allergic and light allergic reaction) [5]". There is no specific detection techniques and methods available to evaluate anaphylactoid reactions caused by TCMIs in non-clinical stage. But recent 
reports showed that some TCMIs and their cosolvent (Tween 80 ) can cause degranulation of RBL-2H3 cells in vitro [6,7] and mast cells in vivo [8].

In this study, in order to establish techniques and methods for detecting anaphylactoid reactions, we investigated RBL-2H3 cell degranulation phenomena induced by some TCMIs through cell morphological and ultrastructural observation, released enzyme activity detection, and established the RBL-2H3 cell degranulation test to $\operatorname{detect} \beta$-hexosaminidase activity induced by some TCMI, then discussing the degranulation mechanism and some influence factors related to this test.

\section{Materials and Methods}

\subsection{Cells}

RBL-2H3 cell line (Wistar rat basophilic leukemia cell line), and BRL cell line (Buffalo rat liver cells) were purchased from the cell bank of the Chinese Academy of Sciences. RBL-2H3 cell line was cultured in MEM medium containing $10 \%$ fetal calf serum and $100 \mathrm{U} / \mathrm{ml}$ penicillin and $100 \mathrm{ug} / \mathrm{ml}$ streptomycin, and BRL cell line was cultured in high glucose DMEM medium containing 15\% fetal calf serum and $100 \mathrm{U} / \mathrm{ml}$ penicillin and $100 \mathrm{ug} / \mathrm{ml}$ streptomycin. The 2 cell lines were incubated in a humidified incubator at $37^{\circ} \mathrm{C}, 5 \% \mathrm{CO}_{2}$. When the cells covered approximately $80 \%$ of the bottom area of culture flask, passage could be done by ratio of 1:3.

\subsection{Reagents}

The positive control chemical C48/80 (Compound 48/80) was purchased from Sigma Company, and diluted with sterilized normal saline to $1 \mathrm{mg} / \mathrm{ml}$ as stock solution. Tyrode's buffer ( $\mathrm{pH} 7.4, \mathrm{NaCl} 7.5972 \mathrm{~g}, \mathrm{MgCl}_{2} 0.2033 \mathrm{~g}$, $\mathrm{KCl} 0.3728 \mathrm{~g}, \mathrm{CaCl}_{2} 0.1554 \mathrm{~g}$, glucose $1.0 \mathrm{~g}$, dissolved in $1000 \mathrm{ml}$ distilled water). Cell Counting kit (CCK-8, Japan Institute of Chemistry Colleagues). $\beta$-hexosaminidase substrate $(1 \mathrm{mmol} / \mathrm{L}$ 4-nitroPheny1-N-acety1- $\beta$-Dglucosaminide diluted with $0.05 \mathrm{~mol} / \mathrm{L}$ citrate buffer, $\mathrm{pH}$ 4.5), purchased from sigma company. Reaction stop solution $\left(100 \mathrm{mmol} / \mathrm{L} \quad \mathrm{Na}_{2} \mathrm{CO}_{3}, 100 \mathrm{mmol} / \mathrm{L} \quad \mathrm{NaHCO}_{3}\right.$ buffer, $\mathrm{pH}$ 10.7). 17 kinds of Traditional Chinese Medicine Injections (TCMI) were obtained from Shanghai institute for food and drug control, which included Ciwujia injection, Danhong injection, Danshen injection, Danxiangguanxin injection, Dengzhanhua injection, Gualoupi injection, Guanxinning injection, Huangqi injection, Mailuoning injection, Qingkailing injection, Shengmai injection, Shenmai injection, Shuxuening injection, Tanreqing injection, Xiangdan injection, Yinxing injection and Yinzhihuang injection. The 8 kind ingredients of TCMI were kindly given by manufacturer. Chlorogenic acid was purchased from National Institutes for Food and Drug Control.

\subsection{Morphological Study by Toluidine Blue Staining}

RBL-2H3 cells $\left(1 \times 10^{5} /\right.$ well $)$ in 48 -well plates after $24 \mathrm{~h}$ culture were washed with HBSS(GIBCO), and divided into 4 groups: negative control group, positive control group, TCMI group and total enzyme activity group, 5 wells for each group. TCMI group was cultured by adding $500 \mu \mathrm{l}$ of diluted TCMIs, negative group by adding an equal volume of Tyrode's buffer, positive control group by adding an equal volume of $\mathrm{C} 48 / 80$ solution, the total enzyme group by adding an equal volume of $10 \%$ Triton $\mathrm{X}-100$ at $37^{\circ} \mathrm{C}$ for $1 \mathrm{~h}$ for interaction with cells, then the supernatant was taken into sterile $1.5 \mathrm{ml}$ eppendorf tube. After centrifuging at $2000 \mathrm{r} / \mathrm{min}$ for $10 \mathrm{~min}$, the supernatant was drawn for $\beta$-hexosaminidase activity assay, and the remaining cells in 48-well plates were used for staining with toluidine blue. The cells in the wells were fixed by adding $200 \mu \mathrm{l}$ of $100 \%$ methanol for $30 \mathrm{~min}$, then discarded the fixative, stained with $200 \mu \mathrm{l}$ of $0.5 \%$ of toluidine blue dye for $30-45 \mathrm{~min}$, the stained cells were observed under microscope.

\subsection{Ultra-Structural Study by Electronic Microscope Observation}

RBL-2H3 cells in $25 \mathrm{~cm}^{2}$ culture flask $\left(3.0 \times 10^{6} /\right.$ flask $)$ after $24 \mathrm{~h}$ culture were washed three times with Tyrode's buffer. The flasks were divided into the negative control group, positive control group $(\mathrm{C} 48 / 80,50 \mu \mathrm{g} / \mathrm{ml})$ and Qingkailing group (1:5 diluted), then drugs were added and incubated at $37^{\circ} \mathrm{C}$ for $1 \mathrm{~h}$. The culture flasks were washed three times with Tyrode's buffer, and cells were collected by scraping cells with a rubber scraper into 1.5 $\mathrm{ml}$ eppendorf tube, centrifugated at $2000 \mathrm{r} / \mathrm{min}$ for $8 \mathrm{~min}$. Then, the cell pellets were fixed in $2.5 \%$ glutaraldehyde solution followed by osmium tetroxide, embedded in Araldite, cut into ultra-thin slices, stained with Lead citrate and uranyl acetate. The ultra-thin slices were examined under electron microscope.

\section{5. $\beta$-Hexosaminidase and Tryptase Activity Assays}

For detecting $\beta$-hexosaminidase activity, $100 \mu \mathrm{l}$ of the supernatant of each group was added into 96-well plate, plus $100 \mu \mathrm{l}$ of substrate, 5 wells for each test solution, plus 5 wells for the background solution. The mixture was incubated at $37^{\circ} \mathrm{C}$ for $90 \mathrm{~min}$, then $150 \mu \mathrm{l}$ of stop solution was added to stop the reaction. The absorbance at $405 \mathrm{~nm}(O D)$ of each well was measured. The percentage of enzyme release was calculated using the following formula: 


$$
\begin{aligned}
& \beta \text {-hexosaminidase release rate }(\%) \\
& =\frac{O D_{\text {supernatant }}-O D_{\text {background }}}{O D_{\text {Triton } X-100}-O D_{\text {blank }}} \times 100 \%
\end{aligned} .
$$

For detecting tryptase activity, $100 \mu \mathrm{l}$ of the supernatant of each group was added into 96-well plate, plus $30 \mu \mathrm{l}$ of $0.1 \mathrm{~mol} / \mathrm{L}$ Tris-HCI (pH 7.4), $20 \mu \mathrm{l}$ of BAPNA substrate, The mixture was incubated at $37^{\circ} \mathrm{C}$ for $30 \mathrm{~min}$, then add $50 \mu \mathrm{l}$ of $30 \%$ acetic acid to terminate the reaction. The absorbance at $405 \mathrm{~nm}(O D)$ of each well was measured. Trypsin was used as standard for standard curve.

$$
\begin{aligned}
& \text { tryptase release rate }(\%) \\
& =\frac{O D_{\text {supernatant }}-O D_{\text {background }}}{O D_{\text {trypsin }}-O D_{\text {blank }}} \times 100 \%
\end{aligned}
$$

\subsection{Measurement of IC50 of TCMIs on RBL-2H3 and BRL Cells by CCK-8 Assay}

RBL-2H3 and BRL cells were seeded at $4 \times 10^{4} /$ well in 96-well plate $(100 \mu \mathrm{l} /$ well). After $24 \mathrm{~h}$ culture, the wells were divided into blank group, negative control group, C48/80 group (80, 50, 30, 10, 8, 5, $2.5 \mu \mathrm{g} / \mathrm{ml})$ and TCMI group (dilution 1:2, 1:4, 1:8, 1:16, 1:32, 1:64, 1:128), 5 wells for each group. TCMI group was cultured by adding diluted TCMI $100 \mu$, negative group and blank group by adding an equal volume of Tyrode's buffer, C48/80 group by adding an equal volume of $\mathrm{C} 48 / 80$ solution at $37^{\circ} \mathrm{C}$ for $1 \mathrm{~h}$ for interaction with cells, abandoned the supernatant, then added $100 \mu \mathrm{l}$ of $10 \% \mathrm{CCK}-8$ reagent diluted with Tyrode's buffer containing 5\% fetal bovine serum, continued to incubate at $37^{\circ} \mathrm{C}$ for $1 \mathrm{~h}$. The OD values were measured with the microplate reader at absorbance $450 \mathrm{~nm}$.

$$
\begin{aligned}
& \text { Inhibition rate calculated }(\%) \\
& =\frac{1-\operatorname{drug} \text { group } O D}{\text { control } O D} \times 100 \%
\end{aligned}
$$

and calculated $\mathrm{IC}_{50}$ by using GraphPad Prism 5.0 version ( $\mathrm{IC}_{50}$ expressed as the reciprocal dilution).

\subsection{Measurement of Osmotic Pressure Values and $\mathrm{pH}$ Values of Testing Samples}

Measurement of osmotic pressure of testing samples was taken by using Fiske ${ }^{\mathrm{R}}$ Mocro-osmometer, the results were recorded as $\mathrm{mOsm} / \mathrm{kg}$, and measurement of $\mathrm{pH}$ values was taken by using $\mathrm{pH}$-meter.

\subsection{Statistical Analysis}

All data were reported as means \pm standard deviation (SD). Statistical significance was analyzed using one way ANOVA. Values of $P<0.05$ were considered statistically significant.

\section{Results}

\subsection{Morphological Observations on the Degranulation of RBL-2H3 Cells Induced by TCMIs}

\subsubsection{Toluidine Blue Staining}

RBL-2H3 cells in negative control stained with toluidine blue were shown pleomorphic or spindle-shaped, full cytoplasm dyed deep blue, with clearly visible nucleus. While in C48/80 group, after contacting with drugs for 1 $\mathrm{h}$, the normal spindle cells became round cells or tadpole-shaped cells, with cytoplasm disappeared; in Qingkailing group though still showing as spindle cells, but the cytoplasm of all cells was lightly stained, some cells were vacuolated (Figure 1). The different degrees of morphological degranulation also could be seen in some other TCMIs, such as Shenmai injection, Tanreqing Injection, and Yinxing injection.

\subsubsection{Ultra-Structural Changes}

Under electron microscopy, it was found that the normal RBL-2H3 cells differed in size, with cell membranes intact and many microvilli on them. In the cytoplasm were full of dense granules varying in size and density and some expanded endoplasmic reticulums, and nucleuses were lobulated. In cells treated with C48/80, most of the membrane microvilli disappeared, with the membrane inward hollow. The granules in the cytoplasm reduced significantly, and cell endoplasmic reticulum extreme expanded, showing vacuolated. In Qingkailing injection treated cells, the membrane microvilli disappeared, and the granules in the cytoplasm reduced, with the membrane
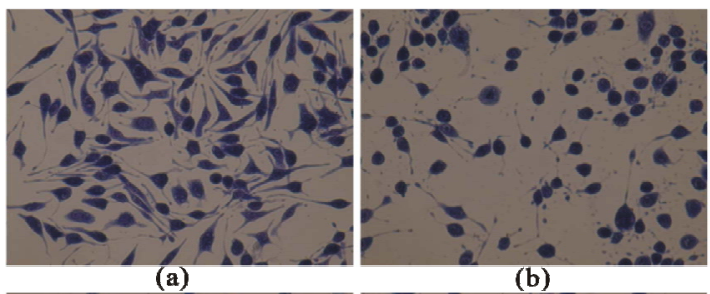

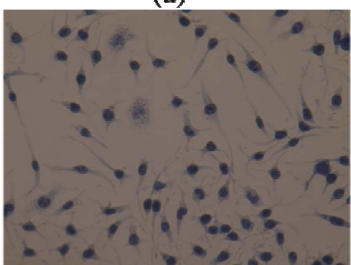

(c)

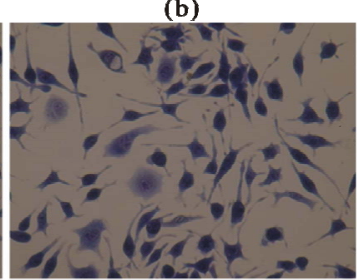

(d)
Figure 1. (a) normalRBL-2H3 cells; (b) RBL-2H3 cells treated with C48/80; (c) RBL-2H3 cells treated with Qingkailing injection; (d) RBL-2H3 cells treated with Shengmai injection. Magnification: $\times 200$. 
uncomplete and inward hollow, endoplasmic reticulum extreme expanded, vesicles and vacuole shape structure increasing, showing typical characteristics of degranulation (Figure 2).

\section{2. $\beta$-Hexosaminidase and Tryptase Release Rates Induced by $\mathbf{C 4 8 / 8 0}$}

Induced by $\mathrm{C} 48 / 80$ at different concentrations $(1.25,2.5$, $5,10,20 \mathrm{mg} / \mathrm{ml})$ and different time $(15,30,45,60 \mathrm{~min})$, the changes of $\beta$-hexosaminidase and tryptase release rates from RBL-2H3 were shown in Figure 3. When $\mathrm{C} 48 / 80$ concentration was at $10-20 \mathrm{mg} / \mathrm{ml}$, and reaction time in $45-60 \mathrm{~min}, \beta$-hexosaminidase release rates were relatively high, while no tryptase activity was shown in this test system, therefore $60 \mathrm{~min}$ reaction time for detecting $\beta$-hexosaminidase activity was chosen duration experiment thereafter.

\section{3. $\beta$-Hexosaminidase Release Rate Induced by TCMIs}

With the dilution of $1: 10$ and 1:20, 17 kings of TCMIs reacted with RBL-2H3 cells respectively for $1 \mathrm{~h}$, then $\beta$-hexosaminidase activity in supernatant was determined. As shown in Table 1, the $\beta$-hexosaminidase release rate in control group was about $10 \%$, while the release rate in positive control reached to $27 \%$. The effects of 17 kinds of TCMIs on inducing RBL-2H3 cells to release $\beta$ hexosaminidase were quite different, the degranulations of induced RBL-2H3 cells were stronger in Shenmai injection, Yinxing injection, Guanxinning injection, Tanreqing injection, Dengzhanhua injection, Qingkailing injection, shengmai injection and Mailuoning injection,

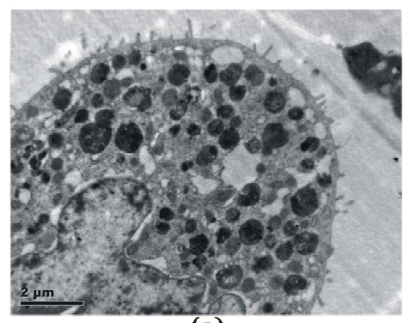

(a)

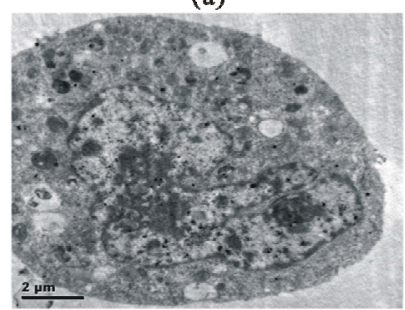

(c)

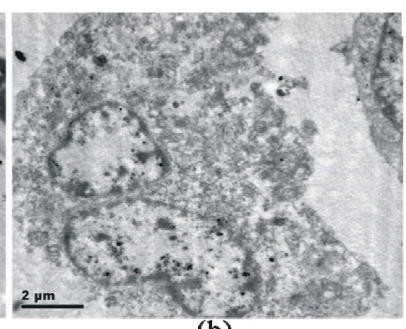

(b)

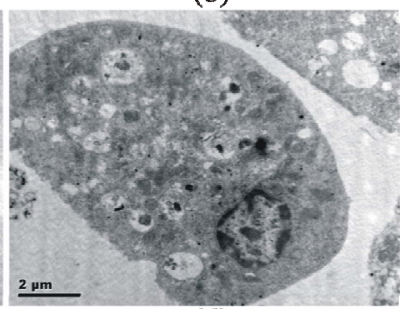

(d)
Figure 2. (a) normal RBL-2H3 cell; (b) RBL-2H3 cells treated with C48/80; (c) RBL-2H3 cells treated with Qingkailing injection; (d) RBL-2H3 cells treated with Qingkailing injection, showing uncomplete and inward hollow membrane.
Table 1. $\beta$-hexosaminidase release rate of $\mathrm{RBL}-2 \mathrm{H} 3$ cells induced by some TCMIs $(\bar{x} \pm s)$.

\begin{tabular}{|c|c|c|c|}
\hline \multirow{2}{*}{ TCMIs } & \multirow{2}{*}{$\mathrm{n}$} & \multicolumn{2}{|c|}{$\begin{array}{c}\beta \text {-hexosaminidase release rate } \\
(\%)\end{array}$} \\
\hline & & $1: 10$ & $1: 20$ \\
\hline Control & 5 & \multicolumn{2}{|c|}{$9.96 \pm 2.74$} \\
\hline $\mathrm{C}_{48 / 80}(20 \mu \mathrm{g} / \mathrm{ml})$ & 5 & \multicolumn{2}{|c|}{$26.71 \pm 21.93$} \\
\hline Ciwujia injection & 5 & $10.03 \pm 8.31$ & $14.76 \pm 7.02$ \\
\hline Danhong injection & 5 & $8.26 \pm 3.21$ & $8.80 \pm 4.22$ \\
\hline Danshen injection & 5 & $-9.55 \pm 21.70$ & $4.70 \pm 12.75$ \\
\hline Danxiangguanxin injection & 5 & $-47.52 \pm 2.67$ & $-43.15 \pm 0.35$ \\
\hline Dengzhanhua injection & 5 & $32.37 \pm 18.42$ & $22.58 \pm 12.96$ \\
\hline Gualoupi injection & 5 & $9.57 \pm 4.86$ & $8.70 \pm 9.10$ \\
\hline Guanxinning injection & 5 & $29.49 \pm 10.23$ & $31.65 \pm 4.47$ \\
\hline Huangqi injection & 5 & $0.53 \pm 0.22$ & $1.36 \pm 0.13$ \\
\hline Mailuoning injection & 5 & $61.21 \pm 3.47^{*}$ & $66.15 \pm 3.44^{*}$ \\
\hline Qingkailing injection & 5 & $58.90 \pm 11.60^{*}$ & $13.13 \pm 22.02$ \\
\hline Shengmai injection & 5 & $24.11 \pm 9.51$ & $20.33 \pm 8.65$ \\
\hline Shenmai injection & 5 & $45.04 \pm 2.97^{*}$ & $44.71 \pm 2.58^{*}$ \\
\hline Shuxuening injection & 5 & $-9.81 \pm 8.23$ & $6.18 \pm 3.52$ \\
\hline Tanreqing injection & 5 & $64.11 \pm 32.34^{*}$ & $66.34 \pm 7.52^{*}$ \\
\hline Xiangdan injection & 5 & $11.70 \pm 1.74$ & $12.12 \pm 3.31$ \\
\hline Yinxing injection & 5 & $81.37 \pm 16.13^{*}$ & $77.90 \pm 7.86^{*}$ \\
\hline Yinzhihuang injection & 5 & $12.91 \pm 1.09$ & $11.12 \pm 3.47$ \\
\hline
\end{tabular}

Note: compared with negative control, ${ }^{*} P<0.05$.

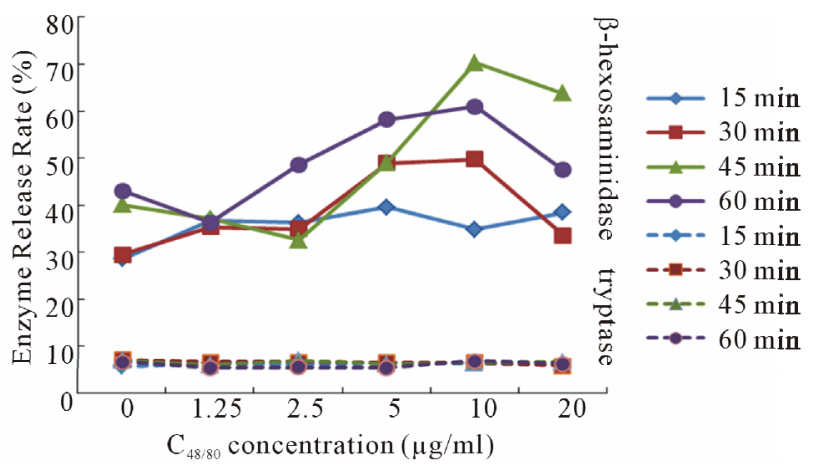

Figure 3. $\beta$-hexosaminidase release rates induced by $C 48 / 80$.

the release rates in all of them were over $20 \%$. Compared with the negative control, the release rates in most of 
them were statistically significant difference $(P<0.05)$, while the release rates in Huangqi injection, Danxiangguanxin injection, Danshen injection, Xiangdan injection, Ciwujia injection, Shuxuening injection, Yinzhihuang Injection, Danhong injection and Gualoupi injection were below $20 \%$, and there were no statistically different when compared with negative control.

\section{4. $\beta$-Hexosaminidase Release Rates Induced by Each Ingredients of Tanreqing Injection and Shengmai Injection}

Each ingredient of Tanreqing injection and Shengmai injection (the final dilutions were equal to $1: 10$ and $1: 20$ of each injection) was taken to react with RBL-2H3 cells for $1 \mathrm{~h}$, then the release rates of $\beta$-hexosaminidase in supernatant were determined. As shown in Table 2, the ingredients Scutellaria baicalensis of Tanreqing injection, and the ingredients Red ginseng and Schisandra Chinensis of Shengmai injection could induce the degranulationof RBL-2H3 cells obviously, the release rates were over $20 \%$, and had significant statistically when compared with the negative control.

\subsection{The Cytotoxicity Effect of 17 Kinds of TCMIs on RBL-2H3 and BRL Cells}

The values of half inhibitory concentration $\left(\mathrm{IC}_{50}\right)$ of 17 kinds of TCMIs were determined on RBL-2H3 and BRL cells by CCK-8, the results expressed by the reciprocal of

Table 2. The effect of ingredients on the release rates of $\beta$-hexosaminidase of RBL-2H3 cells.

\begin{tabular}{|c|c|c|c|}
\hline \multirow[t]{2}{*}{ Group } & \multirow[t]{2}{*}{$\mathrm{n}$} & \multicolumn{2}{|c|}{$\begin{array}{c}\beta \text {-hexosaminidase release rates } \\
(\%)\end{array}$} \\
\hline & & $1: 10$ & $1: 20$ \\
\hline Control & 5 & \multicolumn{2}{|c|}{$10.02 \pm 3.48$} \\
\hline $\mathrm{C}_{48 / 80}(20 \mu \mathrm{g} / \mathrm{ml})$ & 5 & \multicolumn{2}{|c|}{$28.81 \pm 8.80$} \\
\hline \multicolumn{4}{|l|}{ Tanreqing's ingredients } \\
\hline Beer gall powder & 5 & $6.54 \pm 9.32$ & $1.35 \pm 0.61$ \\
\hline Honeysuckle & 5 & $7.08 \pm 2.04$ & $9.24 \pm 1.39$ \\
\hline Goat horn & 5 & $6.07 \pm 4.52$ & $15.47 \pm 13.75$ \\
\hline Scutellaria baicalensis Georgi & 5 & $71.01 \pm 36.27^{*}$ & $42.82 \pm 37.94$ \\
\hline Weeping forsythia & 5 & $2.08 \pm 1.02$ & $4.23 \pm 1.84$ \\
\hline \multicolumn{4}{|l|}{ Shengmai's ingredients } \\
\hline $\begin{array}{l}\text { Fructus Schisandrae } \\
\text { Chinensis }\end{array}$ & 5 & $34.34 \pm 4.25$ & $37.71 \pm 9.61$ \\
\hline Ophiopogon japonicus & 5 & $6.87 \pm 3.87$ & $3.25 \pm 1.66$ \\
\hline Red ginseng & 5 & $32.43 \pm 18.05$ & $22.36 \pm 3.81$ \\
\hline
\end{tabular}

Note: compared with negative control, ${ }^{*} P<0.05$. dilution (Table 3). If the $\mathrm{IC}_{50} \leq 0.1$ (1:10 dilution) is determined as cytotoxic, then the 5 kinds of TCMIs, Xiangdan, Mailuoning, Guanxinning, Tanreqing and Qingkailing, had toxicity on both RBL-2H3 and BRL cells. However, the toxicity $\left(\mathrm{IC}_{50}\right)$ on RBL-2H3 cells was relatively stronger than that on BRL cells, indicating that these 5 kinds of TCM injections inducing RBL-2H3 cell degranulation is in part due to cytotoxicity. The Yinxing injection had no toxicity on both RBL-2H3 and BRL cells, but the release rate of $\beta$-hexosaminidase was high, suggesting that Yinxing injection induce RBL-2H3 cell degranulation by non-cytotoxic way.

\subsection{Correlation Analysis on IC50 Values between RBL-2H3 and BRL Cells}

The correlation analysis has been done on $\mathrm{IC}_{50}$ values of 17 kinds of TCM injections, and the $|r|$ value is about 0.61 , suggesting that a little cytotoxicity correlation exists between the two cell lines.

Table 3. The IC50 values of RBL-2H3 and BRL cells caused by some TCM injections.

\begin{tabular}{|c|c|c|c|}
\hline \multirow{2}{*}{ TCMIs } & \multirow{2}{*}{ Degranulation $^{*}$} & \multicolumn{2}{|c|}{$\mathrm{IC}_{50}$} \\
\hline & & RBL-2H3 & BRL \\
\hline Ciwujia injection & - & $>0.5$ & 0.72 \\
\hline Danhong injection & - & 0.2 & 0.25 \\
\hline Danshen injection & - & 0.12 & 0.13 \\
\hline $\begin{array}{l}\text { Danxiangguanxin } \\
\text { injection }\end{array}$ & - & 0.24 & 0.12 \\
\hline Dengzhanhua injection & + & $>0.5$ & $>0.5$ \\
\hline Gualoupi injection & - & 0.16 & $>0.5$ \\
\hline Guanxinning injection & + & 0.006 & 0.07 \\
\hline Huangqi injection & - & 0.16 & $>0.5$ \\
\hline Mailuoning injection & +++ & 0.05 & 0.05 \\
\hline Qingkailing injection & ++ & 0.03 & 0.05 \\
\hline Shengmai injection & + & $>0.5$ & $>0.5$ \\
\hline Shenmai injection & ++ & 0.002 & $>0.5$ \\
\hline Shuxuening injection & - & $>0.5$ & 0.38 \\
\hline Tanreqing injection & +++ & 0.008 & 0.03 \\
\hline Xiangdan injection & - & 0.04 & 0.1 \\
\hline Yinxing injection & t+++ & $>0.5$ & $>0.5$ \\
\hline Yinzhihuang injection & - & 0.17 & 0.7 \\
\hline
\end{tabular}




\subsection{Measurement of Osmotic Pressures and pH Values of 17 Kinds of TCMIs}

In order to exclude the influence of some factors on the release rate of $\beta$-hexosaminidase, the osmotic pressures and $\mathrm{pH}$ values of 15 kinds of TCMIs was measured. The results showed that the osmotic pressures of the most of the TCMI samples were within the normal range (290 mOsm $\mathrm{kg}^{-1} \pm 20 \%$ ), while the osmotic pressures of Tanreqing injection was $45 \%$ higher than that of normal saline (Table 4), which showed high release rate of $\beta$ hexosaminidase, indicating that high osmotic pressure of testing sample may destroy RBL-2H3 cells, thus releasing the enzyme.

\subsection{Measurement of $\boldsymbol{\beta}$-Hexosaminidase Release Rates, Osmotic Pressures and pH Values of Chlorogenic Acid}

The different concentrations of chlorogenic acid were

Table 4. Relation between osmotic pressure, $\mathrm{pH}$ and release rates of $\boldsymbol{\beta}$-hexosaminidase.

\begin{tabular}{|c|c|c|c|}
\hline $\begin{array}{c}\text { TCMIs } \\
\text { (dilution 1:10) }\end{array}$ & $\begin{array}{c}\text { Osmotic } \\
\text { pressure } \\
(\mathrm{mOsm} / \mathrm{kg})^{*}\end{array}$ & $\mathrm{pH}$ & $\begin{array}{l}\beta \text {-hexosaminidase } \\
\text { release rate }^{* *}\end{array}$ \\
\hline Ciwujia injection & $258^{(-)}$ & 5.2 & - \\
\hline Danshen injection & $217^{(--)}$ & 5.05 & - \\
\hline $\begin{array}{l}\text { Dengzhanhua } \\
\text { injection }\end{array}$ & 286 & ND & + \\
\hline Huangqi injection & 274 & 6.65 & - \\
\hline Danhong injection & $259^{(-)}$ & 5.37 & - \\
\hline $\begin{array}{l}\text { Danxiangguanxin } \\
\text { injection }\end{array}$ & 300 & ND & - \\
\hline Gualoupi injection & $245^{(-)}$ & 5.91 & - \\
\hline $\begin{array}{l}\text { Guanxinning } \\
\text { injection }\end{array}$ & 286 & 5.75 & + \\
\hline Mailuoning injection & ND & ND & ++t \\
\hline Qingkailing injection & 298 & 7.07 & ++ \\
\hline Shenmai injection & $233^{(-)}$ & 5.44 & ++ \\
\hline Shengmai injection & 270 & 6.71 & + \\
\hline Shuxuening injection & $347^{(+)}$ & 5.35 & - \\
\hline Tanreqing injection & $419^{(++++)}$ & 7.17 & +++ \\
\hline $\begin{array}{l}\text { Yinzhihuang } \\
\text { injection }\end{array}$ & $248^{(-)}$ & 5.76 & - \\
\hline Normal saline & 291 & 7.10 & ND \\
\hline Tyrode's buffer & 283 & 7.14 & - \\
\hline
\end{tabular}

Note: " "+" or "-" indicates the Osmotic pressure is higher or lower than $10 \%$ of normal saline. "**" indicates the release rates of $\beta$-hexosaminidase between $21 \%-40 \%$, “+”, between $41 \%-60 \%$, “+++" between $61 \%-80 \%$, “+++", higher than $81 \%$. ND: not done. taken to react with RBL-2H3 cells for $1 \mathrm{~h}$, then the release rates of $\beta$-hexosaminidase in supernatant were determined. As shown in Table 5, the release rates of $\beta$ hexosaminidase in supernatant rised as the concentrations of chlorogenic acid increased. There were significant statistically in 2.5 and $5.0 \mathrm{mmol} / \mathrm{L}$ group, but when the concentration of chlorogenic acid reach $10 \mathrm{mmol} / \mathrm{L}$, the release rate drop sharply.

The osmotic pressures of different concentrations of Chlorogenic acid was almost the same, but the $\mathrm{pH}$ values was very low, and decreased as the concentration increased.

\subsection{Influence of Sample pH on the Release Rate of $\beta$-Hexosaminidase}

In order to explore whether the low $\mathrm{pH}$ could cause degranulation of RBL-2H3, we adjust the $\mathrm{pH}$ values of Tyrode's buffer to 2.5, 3.0, 3.5, 4.0, 4.5, 5.0, 5.5, 6.0, 6.5, 7.0 respectively as test samples. The results showed that when the $\mathrm{pH}$ of test sample between 3.0 and 3.5, the release rate of $\beta$-hexosaminidase increase to above $50 \%$, then drop to $10 \%$ at $\mathrm{pH} 4.0$ afterward (Figure 4).

\subsection{Comparison of Chlorogenic Acid Samples between $\mathrm{pH}$ Unadjusted and $\mathrm{pH}$ Adjusted to 7.0}

Chlorogenic acid was diluted to the concentration of

Table 5. The relation between osmotic pressure, $\mathrm{pH}$ and release rates of $\boldsymbol{\beta}$-hexosaminidase.

\begin{tabular}{cccc}
\hline Chlorogenic acid & $\begin{array}{c}\text { Osmotic pressure } \\
(\mathrm{mOsm} / \mathrm{kg})^{*}\end{array}$ & $\mathrm{pH}$ & $\begin{array}{c}\beta \text {-hexosaminidase } \\
\text { release rate }\end{array}$ \\
\hline $0.63 \mathrm{mmol} \cdot \mathrm{L}^{-1}$ & 285 & 3.74 & $25.23 \pm 2.87$ \\
$1.25 \mathrm{mmol} \cdot \mathrm{L}^{-1}$ & 285 & 3.55 & $-40.19 \pm 4.54$ \\
$2.5 \mathrm{mmol} \cdot \mathrm{L}^{-1}$ & 283 & 3.34 & $53.45 \pm 4.27$ \\
$5.0 \mathrm{mmol} \cdot \mathrm{L}^{-1}$ & 285 & 3.15 & $40.74 \pm 6.77$ \\
$10.0 \mathrm{mmol} \cdot \mathrm{L}^{-1}$ & 285 & 2.92 & $-29.82 \pm 8.14$ \\
\hline
\end{tabular}

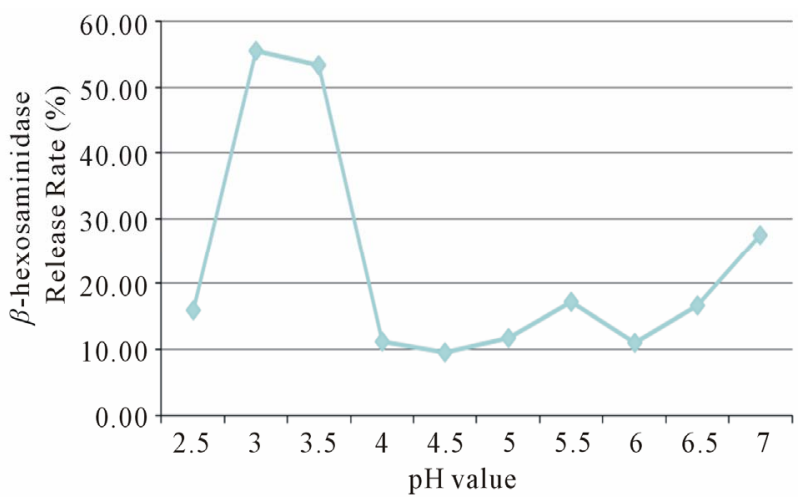

Figure 4. A model of RBL-2H3 degranulation caused by different $\mathrm{pH}$ values of Tyrode's buffer. 
$0.625,1.25,2.5,5.0$ and $10 \mathrm{mmol} / \mathrm{L}$, which included $\mathrm{pH}$ unadjusted and $\mathrm{pH}$ adjusted to 7.0 in each concentration, then cocultured with RBL-2H3 cells. The results showed that all the $\mathrm{pH}$ adjusted chlorogenic acid did not cause $\beta$ hexosaminidase release, while chlorogenic acid at 2.5 and $5.0 \mathrm{mmol} / \mathrm{L}$ which $\mathrm{pH}$ were not adjusted showed high $\beta$-hexosaminidase release rate above $40 \%$, at which concentration, the $\mathrm{pH}$ values were 3.34 and 3.15 (Figure 5), indicating that RBL-2H3 cell degranulation is not caused by chlorogenic acid, but by low $\mathrm{pH}$.

\section{Discussion}

TCMIs are a new type of preparation (including solution type and powder type) made from single or multi-ingredients Chinese drugs or natural drugs by using modern science and technology. It can be used clinically by intramuscular injection, intravenous injection or infusion, point injection and other routes of administration into the body to treat certain diseases. Because this new preparation has the advantages of rapid effecting, stronger efficacy, and easy to use, applying traditional Chinese medicine to the field of clinical emergency and severe cases become a reality. This has important theoretical and practical significance for the development of traditional Chinese medicine.

However, TCMIs also appear likely to endanger their survival and development problem. That is, in the clinical practice, some adverse reactions occur, and even endanger the lives of patients, while in preclinical safety evaluation almost all TCMIs have been found no significant positive results by using authorized routine methods.

From the reports of "Adverse Drug Reaction Information Bulletin" published by SFDA, many cases showed adverse events with TCMIs at the first time treated. Some scholars have noted the relationship between adverse reaction and TCMIs, and try to establish some methods as indicators to detect anaphylactoid reactions in vitro and in vivo, and to clarify the mechanism of anaphylactoid reactions caused by TCMIs. It was reported that several TCMIs could cause RBL-2H3 cell significant

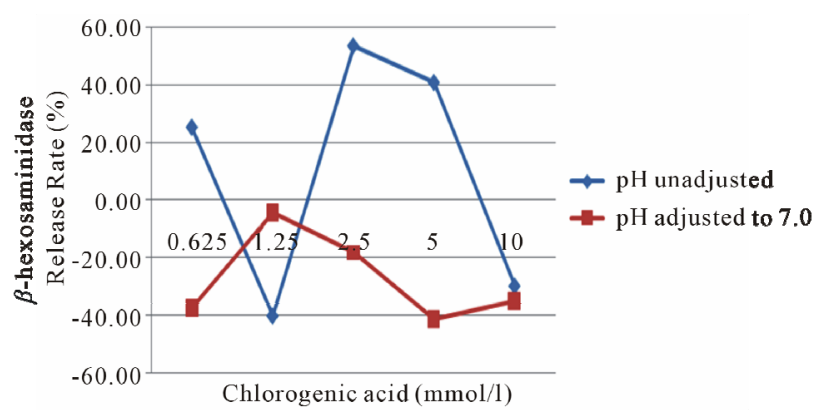

Figure 5. Comparison of chlorogenic acid samples between pH unadjusted and pH adjusted to 7.0. degranulation in vitro, and increase the level of $\beta$-hexosaminidase in supernatant $[6,7]$. ZHANG et al. found that cosolvent Tween-80 and RBL-2H3 cell line co-culture in vitro could be result in RBL-2H3 degranulation, and there was a clear dose-effect relationship [9]. Therefore, it is essential to establish reliable, stable, and sensible methods as indicators to evaluate the potential anaphylactoid reaction caused by TCMIs in non-clinical stage.

Our results show that some TCMIs do cause degranulation of RBL-2H3 cells by the evidences of cell morphological examination (toluidine blue staining) and ultra-structral observation (electronic microscope observation), but it is difficult to quantificat the results and to be objective endpoint by toluidine blue staining, and the electronic microscope observation cannot used as routine examination.

Detecting the bio-active materials released from mast cells or basophiles, such as histamine, leukotriene, $\beta$-hexosaminidase and tryptase, is common methods for allergic reactions and anaphylactoid reactions. Our results show that $\beta$-hexosaminidase activity is a good indicator for RBL-2H3 degranulation, because this method is simple, stable, and reproducible. Although the color of some TCMIs may interfere with the results, it can be solved by adding background controls. We found little tryptase activity in the supernatant could be detected, which may be attributed to the lower enzyme activity in the granules of RBL-2H3 cells themselves. Therefore, the tryptase activity does not a sensitive indicator for detecting RBL$2 \mathrm{H} 3$ cell degranulation.

Our results shown that some TCMIs could induce RBL-2H3 degranulation by detecting $\beta$-hexosaminidase activity, while others not. Calculated according to the release rate, Yinxing injection, Tanreqing injection, and Mailuoning injection were considered as the strong inducer, and Qingkailing Injection, Shenmai injection as medium, while Guanxinning injection and Shengmai injection as weak inducer. The other 10 kinds of TCMIs could not induce RBL-2H3 degranulation.

To further explore which ingredient caused RBL-2H3 degranulation, we used each ingredient of Tanreqing injection and Shengmai injection to detect their effect on RBL-2H3 cell degranulation. It was found that among the 5 kind ingredients in Tanreqing injection, only Scutellaria baicalensis Georgi was the strong inducers, while the other 4 ingredients were not; among the 3 kind ingredients in Shengmai injection, red ginseng and Fructus Schisandrae Chinensis were the weak inducers, while Ophiopogon japonicus was not, suggesting this method can be used for analyze which ingredients induce RBL$2 \mathrm{H} 3$ cell degranulation.

The results of RBL-2H3 cell degranulation test can be interfered with the physical-chemical characteristics of tested samples, such as osmotic pressure and $\mathrm{pH}$. In most 
of the TCMIs osmotic pressure and $\mathrm{pH}$ have been adjusted to allowable value range before marketing. In the testing system, after dilution, the osmotic pressure and $\mathrm{pH}$ values of test samples were within the normal ranges, but in this study Tanreqing injection was found that its osmotic pressure value was as high as $419 \mathrm{mOsm} / \mathrm{kg}$, about $44.5 \%$ higher than normal osmotic pressure. Therefore its high osmotic pressure was regarded to be the cause of high $\beta$-hexosaminidase release rate.

Chlorogenic acid is a compound existing in many Chinese herbs, such as Lonicera and Forsythia et al. It is regarded as allergen causing type I allergic reactions and anaphylactoid reactions [10-12]. We found that chlorogenic acid at $2.5 \mathrm{mmol} / \mathrm{L}$ to $5.0 \mathrm{mmol} / \mathrm{L}$ could induce RBL-2H3 degranulation, and below these concentration, the enzyme release rate drop sharply. This result is almost in correspondence with the report written by Huang [12]. In order to exclude the other factors causing degranulation, we tested the osmotic pressures and $\mathrm{pH}$ values of these concentrations. It was found that the osmotic pressure values at $1.25 \mathrm{mmol} / \mathrm{L}, 2.5 \mathrm{mmol} / \mathrm{L}$, and $5.0 \mathrm{mmol} / \mathrm{L}$ were within the normal range, while the $\mathrm{pH}$ values at these concentrations were very low, 3.55, 3.34, 3.14 respectively. In order to study whether the low $\mathrm{pH}$ itself could cause RBL-2H3 cell degranulation, we adjusted the $\mathrm{pH}$ of Tyrode's buffer from 2.5 to 7.0 respectively as samples adding to the test system. The results showed that $\mathrm{pH} 3.0$ to 3.5 could cause $\beta$-hexosaminidase activity increases, this $\mathrm{pH}$ range was just in correspondence with the $\mathrm{pH}$ of chlorogenic acid 2.5 $\mathrm{mmol} / \mathrm{L}$ and $5.0 \mathrm{mmol} / \mathrm{L}$ concentration. For the reason why no $\beta$-hexosaminidase activity $\mathrm{pH}$ below 3.0 , the explanation is $\mathrm{pH}$ below 3.0 can inhibit the activity of the enzyme, so that no enzymatic reaction occurs. In order to further prove that low $\mathrm{pH}$ of chlorogenic acid induce RBL-2H3 cell degranulation, we adjusted the $\mathrm{pH}$ of different concentration of chlorogenic acid to 7.0 or so. The results showed that $\beta$-hexosaminidase activity in different concentration of chlorogenic acid after adjusted was not obviously increased, indicating that chlorogenic acid compound itself can not cause mast cells degranulation.

Since the concentration of chlorogenic acid in some TCMIs are very low (about $0.04-0.08 \mathrm{mg} / \mathrm{ml}$ in Dengzhanxixin injection) [13,14], about one twentieth of the test concentration causing degranulation, furthermore both Weeping Forsythia and Honeysuckle contain chlorogenic acid, but did not cause enzyme release, therefore the chlorogenic acid seems unlike to cause mask cell degranulation in vivo.

Finally, in order to answer the question that whether or not the degranulation of RBL-2H3 is caused by cytotoxicity, we determined the $\mathrm{IC}_{50}$ values of both RBL-2H3 and BRL cells. BRL cells are normal rat liver cells and have no degranulation function structurally. It was found that half of tested TCMIs (4/8) causing RBL-2H3 degranulation had cytotoxic effect for both RBL-2H3 and BRL cells, and it seemed that according to the values of $\mathrm{IC}^{50} \mathrm{RBL}-2 \mathrm{H} 3$ cells were more sensitive than BRL cells, though the level of cytotoxic effect determined by $\mathrm{IC}_{50}$ was not in correspondence with the enzyme activity. Some TCMIs had no cytotoxic effect and degranulation, and 3 kinds of TCMIs had obvious degranulation but no cytotoxic effect, suggesting that the degranulation caused by these TCMIs occurs through exicytosis.

The adverse reactions mainly include allergic reactions and anaphylactoid reactions. It is advocated to establish techniques and methods for detecting both of them simultaneously at non-clinical stage, thus reducing the risk of occurrence of adverse reactions clinically. The relation between the degranulations of RBL-2H3 cells in vitro and clinical occurrence of adverse reactions caused by some TCMIs remains further study.

\section{Acknowledgements}

This study was supported by the Important New Drug Innovation Project, Ministry of Science \& Technology (No. 2009ZX09502-002). Authors are grateful to Prof. Lu Xiong, who observed and analyzed electronic microscope pictures, and Director J. I. Shen, Department of Chinese Medicine, Shanghai institute for food and drug control, vice general manager Liu Shaoyong, Shanghai Kaibao Pharmaceutical Co., LTD., who provided testing samples of TCMIs.

\section{REFERENCES}

[1] L. Q. Zhu, Y. G. Xu, P. Wang, Z. Y. Gao and Y. Y. Chen, "Analysis on Cause of ADR Associated with Tranditional Chinese Medicine Injections," China Parmacy, Vol. 18, No. 3, 2007, pp. 215-217.

[2] Y. Q. Zhu and X. H. Hong, "Analysis of Adverse Drug Reaction of Traditional Chinese Medicinal Injection," Lishizhen Medicine and Materia Medica Research, Vol. 18, No. 4, 2007, pp. 1004-1006.

[3] H. D. Schlumberger, "Pseudo-Allergic Reactions to Drugs and Chemicals," Ann Allergy, Vol. 51, No. 2, 1983, pp. 317-324.

[4] M. M. Fisher and B. A. Baldo, "Diagnosis and Investigation of Acute Anaphylactoid Reactions to Anesthetic Drugs," International Anesthesiology Clinics, Vol. 23, No. 3, 1985, pp. 161-173.

[5] Project Group, "Technical Guidelines for Studies of Chinese Medicine \& Natural Drug Immunotoxicity (Allergic and light allergic reaction)," 2005. http://ishare.iask.sina.com.cn/f/16123642.html

[6] X. Luo, Q. Wang, L. Zhou, Y. Dong and Y. P. Jiang, "Effect of Several Traditional Chinese Medicine Injections on Degranulation in RBL-2H3 Cells," Traditional 
Chinese Drug Research \& Clinical Pharmacology, Vol. 20, No. 6, 2009, pp. 506-510.

[7] W. H. Huang and X. Luo, "The Influence of Qingkailing Injection on the Degranulation of RBL-2H3 Cells," Journal of Guiyang College of Traditional Chinese Medicine, Vol. 32, No. 4, 2010, pp. 80-82.

[8] A. H. Liang, C. Y. Li, T. Liu, C. Y. Cao, R. Hao, Y. Yi, J. Guo, H. Yang, H. Yi, Z. Wang and Z. F. Ma, "Animal Models and Methodologies for Evaluation of Chinese Herbal Injection-Induced Pseudoanaphylactoid Reactions," World Science and Technology/Modernization of Traditional Chinese Medicine and Materia Medica, Vol. 12, No. 6, 2010, pp. 998-1004.

[9] J. Zhang, P. Li, Y. K. Li and L. D. Li, "Effect of Tween80 on the Degranulation of RBL-2H3 Cells," Modern Immunology, Vol. 29, No. 3, 2009, pp. 240-245.

[10] Z. He, H.-H. Qu, X.-Q. Wang, Y. Zhao, Y.-F. Li, L.-N. $\mathrm{Hu}$, J.-Q. Lu and Q.-G. Wang, "Allergenicity of Chlorogenic Acid as Hapten," Journal of Beijing University of
Traditional Chinese Medicine, Vol. 33, No. 10, 2010, pp. 667-680.

[11] X. D. Wu, H. R. Yang, D. S. Lin, J. Zhang, F. Luo and X. P. Xu, "Comprehensive Research and Evaluation of Chlorogenic Acid Allergy," Chinese Journal of Chinese Materia Medica, Vol. 35, No. 24, 2010, pp. 3357-3361.

[12] F.-H. Huang, X.-Y. Zhang, L.-Y. Zhang, Q. Li, B. Ni, X. L. Chen and A. Jun, "Mast Cell Degranulation Induced by Chlorogenic Acid," Acta Pharmacologica Sinica, Vol. 31, No. 7, 2010, pp. 849-854.

[13] W. B. Shui, Q. He, J. J. Xu and Y. Y. Cheng, "Concentration Measurement of Chlorogenic Acid and Scutellarin in Denzhan-Xixin Injection," China Journal of Chinese Materia Medica, Vol. 33, No. 4, 2008, pp. 458-459.

[14] Q. R. Yan and S. Q. Wang, "Concentration Measurement of Chlorogenic Acid in Honeysuckle Flower," Hunan Journal of Traditional Chinese Medicine, Vol. 21, No. 6, 2005, pp. 74-75. 